\title{
OBESITY AND CARDIOVASCULAR DISEASES: IS THERE A CONNECTION?*
}

\author{
N. G. Ryndina, P. G. Kravchun, K. M. Borovyk, P. I. Rynchak \\ Kharkiv National Medical University, Kharkiv, Ukraine \\ nryndina81@gmail.com
}

Acute myocardial infarction (AMI) is the most threatening form of coronary heart disease (CHD) today [1-4]. According to statistics, every year in the world more than 15 million new cases of AMI are recorded, and its long-term consequences are determined in months and years. Thus, according to the American Heart Association, over six years after the AMI, $18 \%$ of men and $35 \%$ of women undergo repeated myocardial infarction, $22 \%$ of men and $46 \%$ of women become disabled due to the development of severe heart failure (HF), and in $30-40 \%$ of patients left ventricular (LV) dysfunction occures [1-3].

Despite the fact that mortality from AMI has been gradually declining over the past decades in countries of Western and Eastern Europe, including Ukraine, this condition still leads to approximately one third of all deaths among people over the age of $35[4,5]$. According to WHO forecasts, by the year 2030, mortality from heart disease and stroke will be about 23.6 million people [6]. Thus in 2008, 17.3 million people died from the cardiovascular diseases (CVD), accounting for $30 \%$ of all global deaths. Among them, it is estimated that
7.3 million cases occurred as a result of CHD, and 6.2 million - from a stroke [7].

The Framingham study, which began in 1949 and lasted for 25 years, allowing observation for generations in a particular region, was the first prospective epidemiological study in which data were obtained to assess the impact of risk factors on the development of cardiovascular events. This study gave an idea of prevalence, morbidity, prognosis, influencing factors, and determinants of CVD. The concept of risk factors, which is fundamental and widely used to prevent CVD, has been developed on Framingham research data. This led to coverage of such events as the effects of tobacco use, unhealthy diet, hypodynamia, obesity, elevated blood cholesterol levels, high blood pressure, and the presence of concomitant diabetes with CVD. The above-mentioned risk factors are the main objective of global and national prevention measures aimed decreasing consequences of CVD and other non-communicable diseases [5]. However, the authors of the Framingham scale of risk repeatedly warned that extrapolating the results of their research into other groups of the population without taking into

\footnotetext{
* The authors assume responsibility for the published work.

The authors guarantee absence of competing interests and their own financial interest when carrying out the research and writing the article.

The manuscript was received by the editorial staff 7.05.2018.
} 
account the specifics of the region, socio-political conditions, geographical and climatic features should be with great caution [5].

Rapid globalization, urbanization, aging and the spread of chronic diseases are new challenges for the modern health system, AMI can be prevented, but physical inactivity, abuse of nicotine and loss of traditional dietary the habits of new industrial crops lead to an increase in their prevalence in most countries. In addition, social inequality increases cardiovascular mortality and has a negative impact on lifestyle, such as decreased physical activity and increased obesity in society.

Since the end of the twentieth century, obesity has been recognized not only as a cosmetic but also as a medical and social problem. It is important to note that, before this overweight was perceived by many societies as a sign of well-being or a symbol of high social status. Health workers and the public did not declare obesity as an independent disease and contributed to its inadequate identification, which led to the lack of effective public policies health to combat this pathology.

In 2015, according to the Organization for Economic Cooperation and Development (OECD), $19.5 \%$ of the adult population suffered from obesity. This figure ranges from less than $6 \%$ in Korea and Japan to $30 \%$ or more in Hungary, New Zealand, Mexico, and the United States of America. More than one in four adults suffers from obesity in Australia, Canada, Chile, South Africa and the United Kingdom. During the last decade, the prevalence of overweight and obesity has increased in Canada, France, Mexico, Switzerland and the United States, while in England, Italy, Korea and Spain it has stabilized [8]. In 2010, in the United States, about $68 \%$ of the adult population was overweight and obese [9]. In Canada, $46 \%$ of the adult population suffers from obesity, and in Mexico, every seventh country [10].

Concern is also caused by the situation in European countries. According to the World Health Organization report (WHO), presented on 17 May 2017 in Portugal during the European Congress on Obesity, 29.5\% and $26.8 \%$ of the population of Andorra and the Czech Republic respectively suffer from obesity.
In Ukraine, as of $2017,22.1 \%$ of the population suffers from obesity, that is, almost every fifth citizen of the country. However, there are no obvious signs of epidemic reduction in any country.

Modern society provokes unintentional obesity among its citizens, contributing to the consumption of high-calorie foods with high levels of fats, and at the same time, thanks to technical progress, stimulating a sedentary lifestyle. These social and man-made factors contribute to the increased prevalence of obesity in recent decades. WHO came to the conclusion that the main cause of the global epidemic in the world was the shortage of spontaneous and labor physical activity of the population combined with excessive consumption of fatty high calorie food. The urgency of combating obesity is not only due to its high prevalence, but also to the negative impact on the quality of life of patients and, in particular, the high risk of developing various diseases that lead to early disability and a significant reduction in the life expectancy of people who are obese. It has been established that the rate of development of arterial hypertension $(\mathrm{AH})$ in obesity is $75 \%$, diabetes mellitus type $2-57 \%$, coronary heart disease (CHD) $-20 \%$, diseases of the biliary tract $-30 \%$, osteoarthrosis - $14 \%$, malignant tumors of the mammary gland, uterus and intestine $-11 \%$. It is estimated that the total economic loss associated with obesity exceeds those from oncological diseases [9, 10].

A retrospective analysis of the Framingham study showed that obesity is an independent risk factor for cardiovascular complications, especially in women. The multiple logistic analyses showed that the relative weight of the body (actual weight/ ideal weight) at the beginning of the study played a prognostic role in the development of CHD (angina, unstable angina, AMI, sudden death), heart mortality, heart failure in men. The effect of obesity on the prediction did not depend on age, the level of systolic blood pressure, cholesterol, smoking cigarettes per day, the degree of glomerular filtration rate and the presence of glucose tole-rance disorders. In women, the relative weight of the body had a statistically significant relationship with the development of myocardial infarction, cerebral stroke, heart failure, and also with 
the level of cardiovascular mortality. Obesity has a long-term prognostic value for CVD, especially in patients not older than 50 years. A further increase in body weight with age increases the risk of AMI in both men and women, regardless of the initial body weight or the presence of other risk factors associated with weight gain [11].

In 2004, the results of the large international intercontinental epidemiological study INTERHEART were highlighted at the Congress of the European Society of Cardiologists. This study examined a multicentric cohort of 15,152 patients with AMI from 52 countries worldwide for 10 years.

INTERHEART study has identified nine risk factors, six of which increase the likelihood of the disease, while others reduce it. Thus, the presence of concomitant obesity significantly increased the risk of AMI developing 1.62 times, regardless of age, sex, or region of residence of the patient [12].

The adipose tissue is not only a "storage chamber» of fat, but also an active endocrine and paracrine organ [13]. Different types of the adipose tissue have structural and functional features. Adipocytes of white adipose tissue contain one large fatty bubble, which occupies almost the entire area of the cell, with a nucleus on the periphery. The main tasks of white fatty tissue are the storage of energy in the form of triglycerides and the regulation of energy balance, as well as thermal insulation, the creation of mechanical protection around the bodies in the form of a fatty layer, endocrine function. There are several small fat droplets and numerous mitochondria that contain iron (in cytochromes) and color the adipose tissue into brown color.

The adipose tissue is distinguished by anatomical location, biochemical and metabolic effects. Brown fat in the subcutaneous fat is distributed uniformly mainly in the peripheral zone (in the area of the buttocks and hips). White fatty tissue of visceral localization is characterized by an uneven distribution with excessive accumulation of fat in the area of the upper half of the trunk and on the abdomen (intra-abdominal visceral fat - in the omentum, retroperitoneal region), as well as in the internal organs, including the heart, kidneys and liver (extra-abdominal deposition of visceral fat) [14].

Visceral fat, as a hormonal active substance, carries out a complex role in the body: secretes estrogens (adipocytes promotes the synthesis of estrogens from adrenal androgens), angiotensinogen, prostaglandins, tumor necrosis factor-a (TNF-a), interleukin-6 (IL-6), leptin, resistin, adiponectin, insulin-like growth factor-1 (IGF-1), inhibitor of plasminogen activator-1, fibrinogen. They have a different adverse effect on the cardiovascular system, creating a pro-inflammatory and prothrombotic state, as well as causing endothelial damage and vascular hypertrophy [15].

Adipocytes have been studied for many years, and some processes have received great insights, many areas of fat tissue physiology remain unexplored. Our understanding of how cell events in adipocytes affect the local environment through paracrine interactions and how systemic effects are achieved through endocrine interactions are rudimentary. Although lipid storage and release are the main functions of adipocytes, they also use specific lipid molecules for intracellular signaling and use a multitude of protein factors to communicate with practically every body system. Scientists have shown that an excess of the fatty tissue leads to the development of insulin resistance (IR). Less known, but equally important is that the loss of selective fatty layers is also associated with severe forms of IR [16]. This is partly due to the lack of the storage for lipids under normal conditions. This condition leads to a dysregulation of triglycerides and free fatty acids, as well as specific proteins derived from adipocytes, a group of proteins, which are called adipokines. As the main regulator of systemic storage of lipids, and through the secretion of a number of these adipokines, fatty tissue affects many processes, including energy metabolism, inflammation and pathophysiological changes such as cancer and infectious diseases. Thus, the views of scientists on the horizons have changed significantly over the past 20 years. Initially, fatty tissue was considered an inert storage unit for triglycerides, and the work of the Spiegelman and Flier laboratories [17] in the mid-1980s showed for the first time that adipocytes are a rich source of specific se- 
cretory protein called adipine or complement factor D. In 1994, Jeffrey's group Friedman [18] identified leptin as a specific secretory factor of the fatty tissue, mediating the hormonal axis between the fatty tissue and the brain.

At the same time, scientists described the protein, which was originally called Acrp30, which later became known as adiponectin [19]. Since then, the exclusive club of secretory proteins has been added to additional proteins, including adipokines such as resistin and visfatin and retinol-binding protein-4. Enzymes, such as lipoprotein lipase, are also abundantly produced and isolated from adipocytes. Finally, many proinflammatory cytokines and acute phase markers come from adipocytes. These include glycoprotein-a1, serum amyloid A, homolog-pentaxin-3, C-reactive protein, lipocalin 24 p3, and a multitude of cytokines [11].

Abdominal obesity is seen in the focus of an atherogenic heterogeneity as it contributes to the accumulation of atherogenic risk factors associated with IR. Abdominal obesity, represented by the waist circumference and waisthip ratio, was shown to be a strong predictor of CHD, regardless of the overall degree of obesity, although body mass index (BMI) also affects the risk of CHD [20].

In several regression analyzes, the traditional markers of cardiovascular risk (BMI, low density lipoprotein cholesterol (LDL), and family history of diabetes mellitus type 2) were long-term factors for the accumulation of visceral and subcutaneous fat from young to middle-aged men [21] However, the excessive amount of visceral fat was more pathogenic than subcutaneous one, as it is closely related to cardiometabolic abnomalities and increased supply of free fatty acids to the liver through the portal venous drainage [22]. In this sense, the accumulation of visceral fatty tssue is associated with an increase in the frequency of cases of type 2 diabetes, atherogenic dyslipidaemia and hypertension [23, 24]. It is important to note that in several clinical studies the incidence of visceral abdominal fat correlates with heart failure. The multi-ethnic study of atherosclerosis (MESA) shows a close relationship between visceral fat with increased concentricity and left ventricular hypertrophy [25]. The studies of Health ABC and Cardiovascular
Health [26] have demonstrated a positive relationship between visceral fat and $\mathrm{HF}$, regardless of BMI, waist volume and waist to hip ratio as anthropometric values for predicting the accumulation of visceral fat.

In the study, Dudina A. et al. [27] completed and published in 2011, the SCORE (Systematic Coronary Risk Assessment) scale was used to determine the correlation between BMI and traditional CVD risk factors such as age, smoking, total cholesterol, and systolic blood pressure. According to the results of the analysis obtained from 12 European cohort studies, it was concluded that the increase in BMI for every five units correlates with an increase in cardiovascular mortality by $34 \%$ for men and by $29 \%$ for women.

At the same time in 2007 Hassani et al. [28] published their findings, which indicate that in patients with overweight and CHD who have undergone endovascular treatment of coronary arteries, the percentage of restenoses and mortality from cardiovascular causes is significantly lower than in patients with normal body mass. In 2009, George D. Lundberg et al. [29] confirmed that in patients with HF, the presence of obesity does not worsen the cardiovascular outlook: excess body weight correlates with a decrease in overall mortality by $25 \%$, and in case of obesity of 1 degree the risk of death is reduced by $12 \%$. Thus, the term "paradox of obesity", proposed in 2003 by the American nephrologist Kalantar-Zadeh [30] was fixed. The results of the largest international study of MONICA - Multinational Monitoring of Trends and Determinants in Cardiovascular Disease (a total number of participants of 10 million people aged 25-64 years), aimed to determine the extent to which cardiovascular morbidity depends on known risk factors, as well as daily habits, lifestyle and socio-economic factors, has shown that the classic causes of the onset and progression of atherosclerosis are confirmed only in $15 \%$ of cases in women and $40 \%$ in men. Also, in a systematic review of 40 studies involving 250000 patients, was shown how obesity affects general and coronary mortality in patients with CHD [31]. Over a 3.8-year follow-up, overweight and obese individuals were shown to have a lower risk of both general and cardiovascular mortali- 
ty than those with normal and reduced weight. However, patients with BMI greater than $35 \mathrm{~kg} / \mathrm{m}^{2}$ were more likely to die from cardiac causes without increasing overall mortality.

The study APPROACH (Alberta Provincial Project for Outcome Assessment in Coronary Heart Disease) studied the effect of BMI on overall mortality, depending on the type of treatment for confirmed CHD [32]. More than 30,000 patients were observed for 46 months. They were divided into groups by the level of BMI and the type of treatment of CHD: drug therapy, stenting of coronary arteries and aorta-coronary artery bypass grafting. In a group of patients who received drug therapy with excess body weight or obesity that does not exceed the 1-2 degree, BMI correlated with lower mortality compared with normal weight. However, patients with overweight and moderate obesity were more often subjected to revascularization interventions, despite being less prone to prognostic adverse lesions of the left coronary artery. The last observations were attributed to the fact that these patients more often had hypercholesterolemia, hypertension, impaired glucose tolerance or diabetes.

Analyzing the study involving 26,000 patients who had endovascular CHD treatment, the findings of previous researches were confirmed. BMI in the range of $25-40 \mathrm{~kg} / \mathrm{m}^{2}$ cardiovascular prognosis is less favorable. In this study, completed in 2010 [33], survival in the group of patients with BMI $25-40 \mathrm{~kg} / \mathrm{m}^{2}$ was higher compared with both the extreme indicators of BMI and normal weight.

In 2012, Swedish researchers published a large study of 38,000 patients with acute coronary syndrome [34]. Individuals with hemodynamically significant stenoses, according to the results of coronary angiography, were divided by the degree of BMI into 9 groups. During the 3-year observation period, the highest mortality rate for all causes was recorded in patients with weight deficiency, then with normal weight, and the lowest mortality rate in overweight patients. The same results were observed in the group of almost 29000 people who had coronary artery stenting. Mortality was significantly lowered from the weight-loss group $(12.4 \%)$ to overweight and obese BMI $35 \mathrm{~kg} / \mathrm{m}^{2}$ (3.9\%). Mortality began to increase when BMI rises over $35 \mathrm{~kg} / \mathrm{m}^{2}$. The researchers explained the obtained results by the action of some unidentified factors in patients with overweight, or the presence of cardioprotective effects of adipose tissue.

According to new information, American researchers in a study published on the website of The JAMA Cardiology in February 2018, deny the existence of the so-called "paradox of obesity" [35]. To this end, scientists have collected data from 190000 people out of ten studies from 1964 to 2015. In comparison, it was concluded that in men with overweight (BMI from 25 to $29.9 \mathrm{~kg} / \mathrm{m}^{2}$ ), the probability of CVD is more by $21 \%$, and for women - by $32 \%$. Among people with obesity (BMI ranging from 30 to $39.9 \mathrm{~kg} / \mathrm{m}^{2}$ ), this risk increases to $67 \%$ for men and $85 \%$ for women. But the authors of the study note that the body mass index does not directly affect the life expectancy, but only the risks of dangerous diseases.

Thus today the study of the effect of obesity on the course of cardiovascular diseases, both acute and chronic forms of $\mathrm{CHD}, \mathrm{AH}$, chronic $\mathrm{HF}$, is still an actual and debatable problem of modern medicine of internal diseases. Further researches are needed to study the relationship between adipose tissue and the cardiovascular system abnormalities. 


\section{REFERENCES}

1. Quadros AS, et al. Am Heart J 2012; 164 (4): 553-560. https://doi.org/10.1016/j.ahj.2012.07.022

2. Rosamond W, et al. Circulation 2008; 117: 25-146. https://doi.org/10.1161/CIRCULATIONAHA.107.187998

3. Lloyd-Jones D, et al. Circulation 2010; 121: 948-954. https://doi.org/10.1161/CIRCULATIONAHA.109.192666

4. Nichols M, et al. Eur Heart J 2014; 35: 27-29. https://doi.org/10.1093/eurheartj/ehu299

5. Mendis S. Prog Cardiovasc Dis 2010; 53 (1): 10-14. https://doi.org/10.1016/j.pcad.2010.01.001

6. Rich MW. Am J Geriatr Cardiol 2006; 15 (1): 7-11; quiz 12. https://doi.org/10.1111/j.1076-7460.2006.05273.x

7. Fu G, et al. J Interv Cardiol 2012; 25 (3): 223-234 https://doi.org/10.1111/j.1540-8183.2011.00711.x

8. Cecchini M. A Systematic Rev 2016; 17 (3): 201-210.

9. Cynthia L, et al. JAMA 2014; 311 (8): 806-814. https://doi.org/10.1001/jama.2014.732

10. Carroll M, et al. Gastroenterology 2007; 132: 2087-2102. https://doi.org/10.1053/j.gastro.2007.03.052

11. Hubert HB. Circulation 1993; 10: 968-977.

12. Yusuf S. Paper presented at the European Society for Cardiology Congress 2004, 29 August-1 September, Munich, available at: www.cardiosource.com.

13. Centers for Disease Control and Prevention. Overweight and obesity. Atlanta, 2011. available at: www.cdc.gov/ obesity.

14. Mahabadi AA, et al. Eur Heart J 2009; 30: 850-856. https://doi.org/10.1093/eurheartj/ehn573

15. Wormser D, et al. Lancet 2011; 377: 1085. https://doi.org/10.1016/S0140-6736(11)60105-0

16. He Q, et al. Am J Physiol Endocrinol Metab 2011; 300 (5): 877-885. https://doi.org/10.1152/ajpendo.00626.2010

17. Cook KS, et al. Science 1987; 237: 402-405 https://doi.org/10.1126/science.3299705

18. Zhang Y, et al. Nature 1994; 372: 425-432. https://doi.org/10.1038/372425a0
19. Hu E, et al. J Biol Chem 1996; 271: 10697-10703. https://doi.org/10.1074/jbc.271.15.8977

20. Despres J. Heart 2009; 95: 1118-1124. https://doi.org/10.1136/hrt.2008.151274

21. Skårn SN, et al. Eur J Intern Med 2016; 29: 26-31. https://doi.org/10.1016/j.ejim.2015.11.027

22. Fox CS, et al. Circulation 2007; 116: 39-48. https://doi.org/10.1161/CIRCULATIONAHA.106.675355

23. Lalia AZ, et al. J Clin Endocrinol Metab 2016; 101: 626634. https://doi.org/10.1210/jc.2015-2892

24. Goldani H, et al. Nutr Hosp 2015; 32: 1609-1615.

25. Abbasi SA, et al. Nutr Metab Cardiovasc Dis 2015; 25: 667-676. https://doi.org/10.1016/j.numecd.2015.03.016

26. Djoussé L, et al. Obesity 2012; 20: 1936-1941. https://doi.org/10.1038/oby.2011.320

27. Dudina A, et al. Eur J Cardiovasc Prev Rehabil 2011; 18 (5): 731-742. https://doi.org/10.1177/1741826711412039

28. Hassani SE, et al. J Am Coll Cardiol 2006; 11: 543-547.

29. Lundberg GD. Lancet 2008; 10 (8): 202.

30. Kalantar-Zadeh K, et al. J Am Coll Cardiol 2004; 43: 1439-1444. https://doi.org/10.1016/j.jacc.2003.11.039

31. Romero-Corral A, et al. Lancet 2006; 368: 666-678. https://doi.org/10.1016/S0140-6736(06)69686-4

32. Oreopoulos A, et al. Eur Heart J 2009; 30: 2584-2592. https://doi.org/10.1093/eurheartj/ehp288

33. Rajamanickam A, et al. J Am Coll Cardiol 2010; 55: 10-15. https://doi.org/10.1016/S0735-1097(10)60835-2

34. Angeras O, et al. Eur Heart J 2013; 34 (5): 345-353. https://doi.org/10.1093/eurheartj/ehs217

35. Sadiya S, et al. JAMA Cardiol 2018; 27: 254-261. 


\section{OBESITY AND CARDIOVASCULAR DISEASES: IS THERE A CONNECTION?}

N. G. Ryndina, P. G. Kravchun, K. M. Borovyk, P. I. Rynchak

Kharkiv National Medical University, Kharkiv, Ukraine

nryndina81@gmail.com

The review is about study of the interlinks of obesity and cardiovascular disease occurrence. It is shown the effect of adipose tissue on the prognosis of cardiovascular diseases, both acute and chronic forms of chronic heart disease, chronic heart failure. Problem of "paradox of obesity" is still an actual and debatable problem of modern medicine of internal diseases. Further researches are needed to study the relationship between adipose tissue and the cardiovascular system abnormalities.

Keyw ords: obesity, cardiovascular disease, adipose tissue, prognosis, coronary heart disease.

\section{ХВОРОБИ ТА СЕРЦЕВО-СУДИННІ ЗАХВОРЮВАННЯ: ЧИ Є ЗВ'ЯЗОК?}

Риндіна Н. Г., Кравчун П. Г., Боровик К. М., Ринчак П. І.

Харківський національний медичний університет, м. Харків, Украӥна nryndina81@gmail.com

Огляд присвячений вивченню взаємозв'язків між ожирінням та серцево-судинними захворюваннями. Показано вплив жирової тканини на прогноз серцево-судинних захворювань, як гострих, так і хронічних форм хронічної хвороби серця, хронічної серцевої недостатності. Проблема «парадоксу ожиріння» все ще залишаеться актуальною і дискусійною проблемою сучасної медицини внутрішніх хвороб. Необхідні подальші дослідження для вивчення зв'язку між жировою тканиною та аномаліями серцево-судинної системи.

К лючов і слов а : ожиріння, серцево-судинні захворювання, жирова тканина, прогноз, ішемічна хвороба серця

\section{БОЛЕЗНИ И СЕРДЕЧНО-СОСУДИСТЫЕ ЗАБОЛЕВАНИЯ: ЕСТЬ ЛИ Связь?}

Рындина Н. Г., Кравчун П. Г., Боровик К. М., Рынчак П. И.

Харьковский национальный медицинский университет, г. Харьков, Украина nryndina81@gmail.com

Обзор посвящен изучению взаимосвязей между ожирением и сердечно-сосудистыми заболеваниями. Показано влияние жировой ткани на прогноз сердечно-сосудистых заболеваний, как острых, так и хронических форм хронической болезни сердца, хронической сердечной недостаточности. Проблема «парадокса ожирения» все еще остается актуальной и дискуссионной проблемой современной медицины внутренних болезней. Необходимы дальнейшие исследования для изучения связи между жировой тканью и аномалиями сердечно-сосудистой системы.

Кл ючевые слова: ожирение, сердечно-сосудистые заболевания, жировая ткань, прогноз, ишемическая болезнь сердца. 